\title{
The Legal Implications of Obstacle Racing and Suggested Risk Management Strategies
}

\section{Margaret C. Keiper, Sarah Young, Gil Fried, and Todd Seidler}

\begin{abstract}
This article applies legal theory, case law, and suggested risk management strategies to obstacle events and racing. The history, popularity, and exponential growth of the obstacle racing industry are explored. Trends in the obstacle racing industry are also examined and legal implications that may follow the trends are discussed. Case law, in a variety of scenarios, is used to explain and apply assumption of risk and duty of care to obstacle racing events. Finally, suggested risk management strategies for race organizers are recommended. Course design, medical staffing, waivers, and proper staff training are all discussed.
\end{abstract}

Imagine spending your Saturday morning running up a muddy incline being sprayed from both sides with high-pressure fire hoses, then plunging into opaque, frigid water brimming with ice to slog your way 25-30 feet, and, finally, running through a trench of blazing kerosene-soaked straw with 4-foot high flames! This is a description of just a few of the obstacles that can be found in obstacle racing or challenge events currently sweeping the nation. Since 2010, it is estimated that more than 3 million people have competed in obstacle course racing which Outside Magazine speculated is more than twice the number of people finishing marathons during the same time span (Obstacle racing, 2013). Obstacle races and challenge events "combine mud and trail runs with boot-camp obstructions and even mind games, all designed to result in mental and physical collapse" (Heil, 2011). Participants seem to be attracted to these events because of their novelty, quirkiness, and physical challenge. Further the popularity of obstacle racing is fueled by massive social-media coverage and advertisement.

Obstacle courses can be traced back to the Roman Empire and ancient Greeks for the purposes of enhancing, contesting, and assessing physical fitness for sport and military training. In modern society, military training has traditionally incorporated obstacle courses requiring variable combinations of endurance, strength, agility, coordination, balance, and strategy. In addition, obstacle courses have long been used as valuable tools in physical education curricula to enhance the motor

Keiper (keipe1m@cmich.edu) is with the Dept. of Physical Education and Sport, Central Michigan University, Mount Pleasant, MI. Seidler is with the Dept. of Health, Exercise, and Sports Studies, University of New Mexico, Albuquerque, NM. Young is with the Dept. of Recreation, Park, \& Tourism Studies, Indiana University, Bloomington, IN. Fried is with the College of Business, University of New Haven, West Haven, CT. 
development, cognitive, and emotional learning of youth (Mullins, 2012). With such a long and rich history, obstacle racing and challenge events are certainly not new, but with increasing popularity over the last several years and the emergence of events such as Tough Mudder, Warrior Dash, Muddy Buddy, Spartan Race, Savage Race, and other muddy, obstacle-filled, boot-camp style races, participation in these events has exploded.

The popularity of obstacle racing is fully supported by the numbers associated with participation, revenue, and commercial race providers. The Outdoor Industry Association reported an $85 \%$ increase in extreme event participation from 2006 to 2010 ("Obstacle Course Races Increase," 2013). Most commercial race providers charge entry fees ranging from $\$ 60$ to $\$ 175$ plus generate revenue from parking, merchandise, sponsorship and concession sales. Thus, the participation numbers are not the only dimension with staggering growth, revenue is spiking as well. In 2012, the three top national race series providers each estimated revenue generation well over $\$ 50$ million (Williams, 2012) attracting thousands of participants and creating a "\$150-million-plus industry" (Gregory, 2013).

The top three commercial service providers of obstacle racing in terms of registrations and revenue generation are Warrior Dash, Tough Mudder, and Spartan Race series. Warrior Dash was conceived by Joe Reynolds in 2009 and the races are produced through his event planning company, Red Frog Events (Keneally, 2012). Characterized as a giant party with live bands, beer, and free turkey legs, this event attracts all-comers from stay-at-home moms to former world-class marathon runners. The main focus is on a fun, uniquely physically challenging experience, yet not taken too seriously. Participants, who according to Keneally are $50 \%$ women, are encouraged to show up in costume to take on a 3.1 mile course full of impediments named Muddy Mayhem, Warrior Roast, Giant Cliffhanger, and other somewhat descriptive names.

At the other end of the obstacle racing spectrum are Spartan races which are much more competitive with its founder, Joe DeSensa, pushing to make obstacle course racing an Olympic sport (Rubinkam, 2012). Advertised as the global leader in obstacle racing, Spartan offers variable length races without disclosing the number of obstacles participants will face. Spartan does not provide any advance warning about the obstacles participants might encounter with their website proclaiming there is "fire, mud, water, barbed wire, and occasionally hell on earth. There WILL be obstacles to catch you off guard" (Meltzer, 2012). To exemplify the extreme nature of the Spartan Race series consider the Spartan Death Race, which is the pinnacle of obstacle racing challenging athletes both mentally and physically. The Spartan web site claims

Death Races take place in the unexpectedly challenging terrain of the Green Mountains in and around Pittsfield, Vermont and have lasted over 70 hours. We provide no support. We don't tell you when it starts. We don't tell you when it ends. We don't tell you what it will entail. We want you to fail and encourage you to quit at any time. (Death races, 2013, para. 2)

Tough Mudder, the third of the three major races, seems to be somewhere between the Spartan Race Series and the Warrior Dash. Tough Mudder claims not to be a race at all, but a challenge. Tough Mudder participants must pledge to put teamwork and camaraderie ahead of course time as they navigate a 10- to 12-mile 
course filled with obstacles named Arctic Enema, Electric Eel, and Fire Walker. In 2013, Tough Mudder produced 35 events, which was on par with the other two main race providers. Between the three main commercial race providers there are well over 150 obstacle run events offered annually (Keneally, 2012).

Although Tough Mudder, Warrior Dash, and the Spartan Series are currently the top three commercial race providers, there are also a number of other commercial race providers and the continual addition of new race providers in the industry. Because of the success of Tough Mudder, Warrior Dash, and Spartan Races, numerous other providers and organizations have developed obstacle racing events to enter the market place. Obstacle course races range from the inclusion of foam and inflatable obstacles, to incorporating bicycles and as much mud as possible. Table 1 lists some of the major commercial race providers, a brief description, and the number of races hosted in 2013. More importantly, many noncommercial race providers are also designing and carrying out their own version of 'local' obstacle races. The growth of obstacle racing is undoubtedly great for the sedentary nation; however there are many lingering questions that are associated with the growth in popularity of obstacle racing. Such as, who is creating, building and inspecting these courses? Are there safety codes and minimum safety standards for these types of events?

\section{Incidents in Obstacle Racing}

Obstacle racing events are not without incident with injuries commonly ranging from mild to catastrophic. Take for example a Michigan Tough Mudder in 2013 where over 200 people became ill from a virus in the mud/water (Hillen, 2013). Progressing to a more serious incident, consider the 2009 Tough Guy challenge in England where 600 participants were treated for hypothermia (Heil, 2011). Another example occurred at a West Virginia Tough Mudder event where 19 participants

Table 1 Major Commercial National Obstacle Race Series Providers

\begin{tabular}{llc}
\hline Race provider & Brief description & \# of races in 2013 \\
\hline 5k Foam Fest & 5k race with foam, mud, and obstacles & 24 \\
Merrell Down \& Dirty & 5k and 10k options; military style & 10 \\
Muddy Buddy & 6-7 miles, biking, running, and obstacles & 9 \\
Roc Race & 5k, game-show themed obstacles & 33 \\
Rugged Maniac & 5k, obstacle race, 20+ obstacles & 20 \\
Spartan Race & 5k, 13k, 19k or 64k, extreme obstacles & 64 \\
Tough Mudder & 10-12 mile hardcore obstacle course & 35 \\
Warrior Dash & 3-4 mile course with 12 obstacles & 55 \\
The Zombie Run & 5k, obstacles, 'zombies' chasing participants & 24 \\
\hline
\end{tabular}

Note. The number of races in 2013 was collected from the individual race provider's websites. This table is not all encompassing of all major race providers in the United States. 
flooded the local emergency room "for injuries ranging from heart attacks to electric shock to hypothermia" (Wells \& Wood, 2013b). In addition, at a Philadelphia Tough Mudder 38 racers were treated in the emergency room where about half of them suffered from injuries caused by running through a field of live electrical wires (Dahl, 2013). Finally, in 2013 at a local event in Port Orchard, Washington, two participants injured their ankles and a third broke every bone in her foot on an obstacle called Gravity's Revenge when their descent down a slippery steep pitch was abruptly stopped by rocks at the bottom (Grimley, 2013).

There are also accounts of catastrophic incidents occurring in obstacle racing events. For example, a 21-year-old college student was paralyzed in a Michigan Warrior Dash in 2011 as the result of diving into a shallow mud pit (Ridley, 2012). Similarly, in 2010 a man fractured three vertebrae from diving head first into the mud-pit at the Filthy 5k Mud Run in Richmond, Virginia (Newsome, 2013). Another example of paralysis occurred in South Carolina in 2013 where a participant fell 15 feet from a net obstacle while participating in the O-Run Obstacle Run (Pan, 2013).

While deaths are more the exception than the rule in light of the thousands participating in these events, there have been fatalities as a result of obstacles runs. For example in 2011, at a Warrior Dash event in Kansas City two participants died of heat illness (Wells \& Wood, 2013a). In 2012 at a Dallas-Fort Worth Original Mud Run, a healthy and fit 32-year-old male participant disappeared in the muddy crossing of the Trinity River, and his body was recovered the following day after he did not show up at the finish line (Bassett, 2012; Woodard, 2012). Finally, in 2013, a 28-year-old man drowned while participating in a walk-the-plank obstacle in a Tough Mudder event held in West Virginia. Walking the plank involved participants jumping 12-feet into a manmade mud pond with zero visibility below the water's surface (Krogh, 2013; Wells, 2013). The victim jumped in and never resurfaced.

When people die as a result of participating in recreation and sports activities, questions are raised and issues begin to emerge: What are the risks involved for participants? How are participants informed of the risks? One response to whether participants are informed of the risks is they are choosing to voluntarily expose themselves to the risks inherent in the activities. Meaning, that if an individual were to get hurt while running an obstacle race a valid defense against negligence might be primary assumption of risk, which means an individual chooses to expose himself or herself to known and appreciated dangers (Cotten, 2013a). However, the more important question is: Do the participants truly know, understand, and appreciate the risks associated with obstacle racing?

From a different perspective, another legitimate question is: Who is designing the obstacles and courses? Obstacle racing, despite its tremendous popularity, lacks any kind of governing body or standards. One of the major purposes of a governing body is to provide a reasonably safe environment, reduce injury and ensure minimum safety standards are adhered to by regular assessment of the setting where the event takes place (Swan, Otago, Finch, \& Payne, 2009). With no governing body in place, the obstacle racing industry has become a bit of a free-for-all allowing anyone with physical space to create an obstacle race or host a challenge event.

The issue of not having governance oversight is not only depicted by the allowance of anyone to produce an obstacle race, but also by the trend of one-upmanship among commercial race providers. There is an evident progression in the obstacle racing industry illustrating each major race provider trying to 'out-do' the other. 
For example, in 2013 the Warrior Dash implemented the "Iron Warrior Dash" a 15-20 mile ruthless terrain obstacle course that boasted only having the toughest obstacles. In addition, Tough Mudder implemented the "World's Toughest Mudder," a 24-hr race that challenged participants to run as many laps as possible around an obstacle course in a 24-hr period. Both of these new program offerings seem to be in competition with the Death Race promoted by Spartan Races. As popularity of all events continues to grow this notion of one-upmanship will likely contribute to an increasing number of incidents resulting in injury to participants.

With the explosive growth of obstacle racing and a litigious society like the United States, a question that seems natural to ask is why aren't there more lawsuits surfacing against the providers of these events? Perhaps the lawsuits are looming as the numbers of obstacle course racing participants continue to grow, especially those participants who fail to thoroughly research the events in terms of what to expect before participating. In the meantime, these events provide a great example of walking-the-fine-line of managing risks, and beg a plethora of questions regarding legal liability, risk management, and safety. The purpose of this article is to provide a legal analysis of the issues involved for the organizations planning and sponsoring obstacle course racing as well as provide recommendations for risk management strategies.

\section{Legal Issues and Problems}

When examining potential legal concerns a key area of analysis is foreseeability. Foreseeability is generally based on the likelihood of a given injury such as the potential injury someone can suffer from slipping on a wet floor. The entire array of extreme obstacle sport competitions has the word extreme in the title for a reason as these events are designed to push participants beyond their traditional limits and possibly beyond their perceived limits. Due to the water-related elements in many extreme sports and the real risk of participants getting injured in mud pits, an analogy may be drawn to some of the water-related cases and research already in the literature.

Young, Burns, Bowen, and McCutchen (1982) analyzed 564 diving injuries finding $63 \%$ of those injured were between ages 15-29 and 91\% were male. Of those 564 injuries, about half occurred in rivers, lakes, and oceans. Other studies such as Gabrielsen and Spivey-Teslow (1990) also analyzed diving injuries finding the vast majority of injured divers were males under age 30. A 2007 study by Clements and Otto examined 247 court decisions involving diving from 1990 to 2005 , and once again, discovered $83 \%$ of the victims were male. One of the injury types identified in these cases was caused by a run and plunge action where the victim took a running leap into the body of water. There were 21 such cases in their study $(8.5 \%)$ with an almost equal number of adults and minors with all but one of the cases involving males. Other data from these court cases included 112 cases of quadriplegia or paraplegia, 13 deaths, 71 cases of people diving into shallow water ( 49 men and 22 women) and 28 cases involved horseplay-primarily by men. Men are the greatest majority of participants injured and many of these injuries occur from horseplay or adventurous activities. Event managers need to take special precautions when events have elements men might think are fun or exciting, especially if 
the event hides or downplays potential hazards. Obstacle racing, simply based on the nature of the activity, is undoubtedly fun, exciting, and potentially hazardous. However, it should be noted that the increased high dollar awards/settlements for paralysis cases makes the risk management issues in extreme obstacle races that much more critical (Fried, 1999).

\section{Legal Theory}

The key for any injury claimed by a participant is whether he/she can prove the four elements of negligence, which are duty, breach of duty, proximate cause, and injury (Fried, 1999). Duty can be imposed by statute, codes, or notice of a hazardous condition- often called foreseeability. Actual notice can occur when an event administrator has been told about a hazard or constructive notice where an event administrator should have known about a risk (Seidler, 2012). Notice might be derived from industry knowledge or best practices. Thus, if race organizers know that participants are likely to dive into mud pits they have a duty to make sure the mud pit is safe enough for the anticipated behavior. Even if the race organizer indicated diving is off limits, and puts up signs, warning participants of the dangers, there may still be participants who attempt to dive head first. As a result, duties owed by an extreme event administrator include designing a relatively safe course, pointing out extreme hazards, monitoring participants for signs of distress, and providing appropriate first aid.

Breaching a duty occurs when an event administrator understands a risk yet fails to minimize it. Breach of duty does not mean the event must be entirely safe, rather reasonably safe as it is impossible to prevent all medical emergencies (Seidler, 2012). However, an event administrator will have breached their duty if he/she knows they need to provide first aid assistance, but fails to use a first aid response team. Moreover, many of the commercial obstacle races have thousands of participants in a single event, so providing sufficient medical assistance for the high number of participants is a duty owed by race organizers.

Proximate cause is the direct cause of an injury, meaning that the breach of duty was the cause-in-fact of the individual's injury (Cotten, 2013b). For example, if an event administrator failed to have medical staffing at an event and a participant was more severely injured (i.e., significant blood loss) while waiting for medical staff to arrive on site, then the person may have a legitimate negligence claim.

For every negligence claim there are also numerous defenses with the most common defenses in sport related cases identified as assumption of risk, comparative/contributory negligence, government immunity, and not breaching a duty (i.e., acting reasonably; Fried, 1999). If a participant willingly assumes a known risk the courts are more inclined to let them suffer open and obvious risks associated with participating in the event (Fried, 1999). Comparative and contributory negligence, while different terms and theories, basically stand for the assumption that if someone contributed to their own injury they either should not be allowed to recover or their recovery should be limited based on their own negligent conduct. It should be noted that contributory negligence is only used as a defense in a handful of states (Fried, 1999). Government immunity (as well as nonprofit immunity in several states) protects a government agency and its employees from negligence claims to protect public interests. Volunteer immunity statutes, such as 
one in New Jersey, can also provide possible legislative protection for those who volunteer with certain events (Fried, 1999). Finally, if the event administrator did not have a duty, did not breach a duty, or there was some intervening cause in the injury then participants cannot recover from the event administrator on the basis of negligence (Fried, 1999).

Waivers. Combining both negligence and contract law, waivers represent a way for an event administrator to appropriately warn participants while allowing adult participants to acknowledge the risks of participation and agreeing not to sue if the participant is injured in the normal course of running the event (i.e., regular negligence as opposed to gross negligence which is rarely covered in a waiver). All of the national obstacle race providers have some type of liability waiver they require participants to sign. Tough Mudder, for example, goes as far as reminding participants via signs during the race course "Remember You Signed a Death Waiver" (Perez, 2013).

In essence, the waiver is a risk management tool protecting the event from liability for an injury resulting from the ordinary negligence of the event provider (Cotten \& Cotten, 2005). As with any contract, the terms need to be sufficient with the contract not violating public policy. Thus, in most states, a contract with a minor is a voidable contract because a child under age 18 lacks the capacity or competency to enter into a binding contract (Cotten \& Young, 2007). Violation of public policy entails a situation where the legislature or the courts decide that waivers should not be applied as to prevent or minimize the chance an event will unduly harm the public or might encourage someone to act inappropriately knowing they would be protected by a waiver.

\section{Case Law Analysis}

Currently, there are only a few cases in litigation involving obstacle course races, and while more cases appear to be in the court pipeline, there is existing case law which identifies several salient legal analyses. The first key point of analysis is whether there is an enhanced risk associated with these events raising potential liability issues. Depending upon an affirmative answer to the first question, the next question is what defenses can be used and finally, are they appropriate for the various types of events currently being run? The following analysis represents several negligence cases that can be applied to extreme sport/event cases. These cases reaffirm the concept that an injured party in extreme sports would need to show that the event was more dangerous than participants perceived it to be, or that the event somehow increased the risk of injury to overcome the assumption of risk defense.

In Sheppard v. Midway R-1 School District (1995), Terra Sheppard, a 14-year old girl, participated in a junior high school track meet hosted by Midway R-1 School District. Sheppard alleged that Midway's long jump pit was in an unreasonably dangerous condition because it was not adequately prepared for long jumping. Midway denied that the long jump pit was inadequately prepared and alternatively alleged assumption of the risk as an affirmative defense. The trial court ruled in favor of Midway. On appeal the court relied on a ruling that "the assumed risks in such activities [that fall within the primary assumption of risk category] are not 
those created by a defendant's negligence but rather by the nature of the activity itself" (p. 262-263).

Consequently the court indicated if, as Sheppard contended, her injury was caused not by a risk inherent in the sport of long jumping but rather by Midway's negligence in preparing the pit, secondary, rather than primary assumption of risk applied. Sheppard contended her knee injury was the result of Midway's negligence in preparing and raking the long jump pit. Substantial evidence was presented at trial to establish the long jump pit was inadequately prepared and not reasonably safe. This evidence tended to show that Sheppard's injury resulted not from a bad landing, an inherent risk of the sport of long jumping, but rather from the condition of the pit. By Sheppard contending her injury was a result of the condition of the pit, secondary assumption of risk applied, not primary assumption of risk. There was no question that Sheppard assumed the risks inherent in the sport of long jumping, but she did not necessarily assume the risk of Midway's negligent provision of a dangerous facility. Midway presented substantial evidence to support a finding that Sheppard's injury resulted exclusively from an awkward or bad landing, an inherent risk of participating in the long jump. Due to the conflicting testimony and improper jury instructions the case was remanded for a new trial.

The California Supreme Court divided "assumption of the risk" into two categories: (1) primary assumption of the risk, which affects the duty analysis; and (2) secondary assumption of the risk, which affects the damages analysis (Shin $v$. $A h n, 2007)$. Primary assumption of risk means the plaintiff has voluntarily participated in a sport that includes various inherent risks, and therefore, the defendant is relieved of his or her duty to use due care to avoid the plaintiff suffering an injury as a result of those inherently risky aspects of the sport (Knight v. Jewett, 1992). Therefore, a court must evaluate (1) the fundamental nature of the sport and (2) the defendant's relationship to the sport, to determine if the defendant should be relieved of his or her general duty of care (Shin v. Ahn, 2007) Because courts shy away from changing the nature of a sport it concluded that a duty should not be imposed where doing so "would require that an integral part of the sport be abandoned, or would discourage vigorous participation in sporting events" (Kahn v. East Side Union High School Dist, 2003, p. 104).

In contrast, secondary assumption of the risk affects the damages analysis, rather than the duty analysis (Shin v. Ahn, 2007). In secondary assumption of the risk, the defendant owes the plaintiff a duty, but the plaintiff shares the fault for his or her injury, and therefore, the damages must be apportioned between the parties (Parsons v. Crown Disposal Co., 1997).

In 2005, Brian Martin, a 17-year-old self-described expert skier, lost his balance and fell, injuring his leg, on his second attempt to slide across a rail at the Lower Valley Terrain Park at Whitface. A rail is an obstacle similar to a hand rail which skiers and snowboarders attempt to ride.

Plaintiffs alleged that defendants negligently failed to safely construct and maintain the rail on which Martin was injured (Martin v. State of New York, 2007). Similar to the Sheppard case, the appellate court affirmed the defendant's summary judgment motion examining whether the rail was defective and unreasonably dangerous - and, thus, presented an increased risk beyond that inherent in the sport. In Martin, the plaintiff alleged the rail lacked safety skirting, a standard industry safety feature. Because Martin could not see the safety device was missing, he 
claimed he was unable to appreciate the risks associated with the lack of skirting. However, the court concluded the defendant's duty was to exercise care to make the conditions as safe as they appeared to be and if the risks of the activity were fully comprehended or perfectly obvious, the plaintiff had consented to them (Hyland v State of New York, 2003; Roberts v Boys \& Girls Republic, Inc., 2008; Turcotte $v$ Fell, 1986). The answer would be different if the risk was concealed or if the defendant had increased the risk so that the activity or condition was over and above the usual dangers inherent in the sport.

As a general rule, people have a duty to use due care to avoid injuring others (Knight v. Jewett, 1992). However, dangerous conduct or conditions are often an integral part of participating in sports (Knight); therefore, when a plaintiff is injured while participating in a dangerous sport, the duty analysis becomes intertwined with an exception to the general duty of care rule known as assumption of the risk. The assumption of the risk doctrine provides an exception to the general duty of care rule when a plaintiff is injured while voluntarily participating in a risky activity (Luna v. Vela, 2008).

In Rosencrans v. Dover Images, Ltd (2011), the court set forth the current California law for an assumption of risk defense. In the Rosencrans case, the court was forced to determine whether being crashed into twice by coparticipants was a risk inherent in the sport of motocross. The court framed its argument by stating that the racetrack setting involved speed and jumping so it followed that coparticipants would fall down, and while down, maybe struck by other riders whose views are obscured by the blind corners, blind ramps, dust, and/or other riders (Branco v. Kearny Moto Park, Inc., 1995).

Across the United States, assumption of risk serves as a strong barrier to cases where a participant is injured by the construction/maintenance of a sport facility. In Brown v. City of New York (2010) the plaintiff was injured while playing touch football at a public field owned by the defendant when he dove for the football at the sideline and his knee struck a cement strip which ran alongside the field approximately five feet outside of the sideline. The plaintiff had played at the field previously and was aware of the presence of the cement strip, which was open and obvious. The cement was there for the purpose of holding down the artificial turf surface of the field. The defendant filed a summary judgment motion which was denied by the Supreme Court of New York, but reversed by the appellate court.

The assumption of risk principle also extends to risks associated with the constructing of a playing field and any open and obvious condition thereon (Brown $v$ City of Peekskill, 1995; Colucci v Nansen Park, 1996; Maddox v City of New York, 1985; Manoly v City of New York, 2006; Sykes v County of Erie, 2000; Ziegelmeyer v United States Olympic Comm., 2006). The law is clear in New York, if the risks are known by, or perfectly obvious to the sport participant, he or she has consented to them and the property owner has discharged its duty of care by making the conditions as safe as they appear to be (Joseph v New York Racing Assn., 2006; Morales v Coram Materials Corp., 2009; Turcotte v Fell, 1986)

The defendant in Brown v. City of New York (2010) proved as a matter of law the plaintiff assumed the risk of injury by voluntarily participating in the football game despite his knowledge that doing so could bring him into contact with the open and obvious cement strip in the out-of-bounds area of the field (Ciocchi v Mercy Coll., 2001; Kazlow v City of New York, 1998; Ribaudo v La Salle Inst., 2007; Trevett v 
City of Little Falls, 2006). Because the defendant did not unreasonably increase the risk associated with the activity on the football field, the assumption of risk defense was appropriate. If the plaintiff was able to prove that the facility violated a specific safety standard the outcome could have been different (Kazlow v City of New York, 1998; Merson v Syosset Cent. School Dist., 2001; Miller v Kings Park Cent. School Dist., 2008; Musante v Oceanside Union Free School Dist., 2009; Ribaudo v La Salle Inst., 2007).

Assumption of risk will always focus on whether the participant willingly participated in an event knowing the risk of injury as well as the general condition(s) of the event. Applying this analysis to obstacle course mud runs, many participants willingly enter these events knowing they will encounter obstacles that may challenge their physical, mental, and emotional capabilities. Hence the reason for comprehensive waivers with assumption of risk language for everything from bumps and bruises to death. However, if an obstacle race event has any hidden risks or the organizer does anything that changes the dynamics of the inherent risk in obstacles, then the assumption of risk defense might not work. While this does not prevent a defendant from raising the defense, it will not likely be as effective as if the plaintiff had complete information and knowledge.

\section{Risk Management}

While these cases help solidify the need for event administrators to educate every participant about the course layout, obstacles, and potential hazards, it is imperative to have a risk management plan in place to properly avoid possible claims. The primary purpose of risk management is not to avoid legal liability. Rather, it is to ensure a quality and safe program. Thus, the purpose of risk management for obstacle runs is to provide a reasonably safe, quality experience for everyone involved in the event.

\section{Obvious vs. Hidden Hazards}

Most obstacle runs do a good job of warning participants that they will encounter hazards throughout the course. In fact, many events play up the hazards as part of their marketing strategy, often emphasizing how tough and dangerous their event is. These warnings, however, are not always adequate. One of the most important factors that sports participants need to keep themselves safe is to be able to see and evaluate hazards or dangerous obstacles before deciding how to approach them or to avoid one altogether. Some hazards are obvious and can easily be evaluated by a participant. If a runner decides to challenge a particular hazard, he/she is usually determined to be assuming the risk presented by the hazard. However, when a dangerous condition is not readily observable and a participant is injured by a condition that he/she did not know existed, a strong case can be made that there was no assumption of the risk involved. Cotten (2013a) supported this perspective by stating, "one cannot assume a risk of which one has no knowledge, understanding or appreciation" (p. 83). Further, he added "Courts have ruled that one must not only know of the facts of the danger, but also must comprehend and appreciate the nature of the danger to be confronted" (p. 83). 
One of the most critical examples of hidden hazards in obstacle race courses are the mud pits. When participants are allowed to dive head first into a mud pit, they have no way of knowing how deep it is or the consistency of the bottom. It is common practice with swimming pools, (i.e., often mandated by law) that signs are posted around the shallow parts of the pool, stating "No Diving Allowed" and the depth of the water must be clearly posted. Aquatic professionals understand the extreme danger of diving head first into shallow water, and even with clean, clear water where the diver knows the depth and can see the bottom of the pool, diving is not allowed. Why then do some event managers allow people to dive into murky water or mud of unknown depth and expect them to avoid serious injury? Obstacle course organizers, regardless of the nature of the activity, must ensure that the risks are obvious as opposed to hidden. The following subsections describe common sources of injury in obstacle racing events as well as recommendations to more effectively manage the risks.

Diving. One of the most dangerous activities occurring during obstacle runs is when runners dive head first into mud pits, ponds, rivers or other water-related features. This is especially true when entering water with low or no visibility where participants often perceive the water/mud to be deeper than it really is. Because these head first entries have been the cause of several catastrophic injuries during obstacle events, it is recommended that a strict rule be established precluding diving or headfirst entries. It is important to inform the participants of the rule and that they may be ejected from the event if this rule is violated. Supervisors on the course must be instructed to enforce the "No Head-First Entry" rule as well as not allow anyone along the sidelines to encourage runners to dive.

Some events that have had the no diving rule have had spectators and sometimes even staff members encouraging runners to dive. In addition, it is common for event promoters to market their event using pictures of participants diving through the air, head first into a mud pit. This inconsistency sends a mixed message that tends to negate the rule and should be avoided. In the summer of 2011, James Sa, a student at Hope College was running in a Warrior Dash event in Michigan. As he approached a mud pit, he dove in, broke his neck and became paralyzed from the chest down (Tunison, 2011). There was language in the waiver Sa signed that prohibited diving and the court record revealed

One of the Defendant's employees or agents was stationed near the mud pit with a microphone and loud speaker, acting as an emcee for the event. Over the course of the event, this individual continually enticed, encouraged, and specifically told participants to dive into the mud pit. (Sa v. Red Frog Events, LLC., 2013, p. 2-3)

The Court partially granted the defendant's motion for summary judgment in October 2013, but the case continues.

In addition to rules prohibiting diving and warning of the danger of diving, there are other ways that may be employed to help reduce the likelihood of someone going head first into a mud pit. Developing a method of making participants slow down and enter the pit on their hands and knees can significantly reduce the opportunities for diving. This can be accomplished by constructing a barrier in front of the pit that forces runners to go under and then into the pit. It's important that the barrier be designed so that it does not allow participants to jump over it. 
Drowning. Proper supervision must be in place for any water features on obstacle race courses. In 2012, Tony Weathers entered Fort Worth's "Original Mud Run" with one of the obstacles requiring participants to cross the Trinity River. Weathers, an excellent athlete and strong swimmer went into the water but did not come out (Woodard, 2012), and nobody noticed until his girlfriend, waiting at the finish line, reported his disappearance to race organizers hours later. A search of the river was begun but his body was not found until the following morning. One competitor reported that many people were experiencing difficulties with the water and he estimated that there were three lifeguards and "80 people in the water" (Beil, 2012). When participants enter deep water, enough lifeguards must be present to adequately monitor all participants in the water at any one time.

Another drowning, the first death of a Tough Mudder participant, occurred on April 20, 2013 in West Virginia. Part way through the event, Avishek Sengupta reached an obstacle called Walk the Plank, a 15-foot high wooden platform above a man-made pool of muddy water approximately 15 feet deep and 40 feet wide. Participants were to jump into the icy water and swim to the shore. Avishek jumped in but did not come up. After being underwater for at least eight and a half minutes, he was finally brought to the surface by a rescue diver (Woods, 2013). The incident report from the Berkeley County sheriff's office called it an accidental drowning but also quoted witnesses who said the response time by Tough Mudder's safety crew was inexplicably slow. The cause of death remains a mystery but there has been speculation that another participant was allowed to jump too soon, landing on top of the victim.

For all water obstacles that are deep enough to be over a person's head, it is recommended there be enough aquatic safety personnel available to observe and keep track of each participant while he/she is in the water. This especially true when the water is murky and visibility is limited.

Heat/Cold/Dehydration. About 15,000 people were registered for the two-day Warrior Dash event that took place in Kansas City in July 2011. With high humidity, the heat index exceeded 100 degrees that weekend. The KC Fire Department responded to 13 calls for assistance from the obstacle course event with six people taken to the hospital and two dying from heat illness. Similarly, there seems to be a high prevalence of hypothermia in many obstacle events which is likely attributed to cold conditions mixed with participants becoming wet. When the weather is extremely hot or cold, contingency plans need to be developed and implemented which ensure there are adequate cooling stations, warming tents and/or water stops for the conditions. If there's any doubt about the safety of the environmental conditions, medical professionals should be consulted about postponing or cancelling the event.

Obstacles. Constructed obstacles must be designed and built by people who are qualified. If a group of volunteers get together to figure out and build an obstacle, is it going to perform the way the runners expect it to? Climbing walls, horizontal ladders, bridges, etc. should be designed by qualified engineers, built by qualified carpenters and should be over-designed and over-built for the expected use. If the maximum number of people expected to be on a climbing wall is 15 , what will happen to the wall if suddenly there are 25,35 , or even 50 people on it? Will it take the added load without collapsing? All obstacles including slides, tunnels and barriers should be evaluated for safety before the event begins. 
Since the range of preparation, fitness and skill of the participants is diverse, it is a good practice to either allow runners to bypass a particular obstacle or to have similar obstacles of varying risk/difficulty next to each other so that each participant is able to choose his/her challenge. An obstacle called Gravity's Revenge was the site of several serious injuries in the Extreme K Mud Run in 2012 (Grimley, 2013). A steep slope leading to a streambed was covered with a tarp and then watered to make it very slippery. Sliding down the tarp, participants reportedly reached a high rate of speed before landing on the rock-covered streambed below. After several severe leg injuries occurred, the EMT's onsite requested that the obstacle be shut down. There was some controversy over whether an alternate method of navigating the obstacle was available.

Finally, it is recommended that hazards presented by each obstacle be open and obvious to the participants, who can then make an informed decision whether to assume the risk of confronting an obstacle. When there is still some element of danger that is not obvious to participants, warnings should be given so they have adequate knowledge to keep themselves safe. Effective use of signage throughout the course can be effective in warning participants of the dangers of specific obstacles. Knowing, understanding and appreciating a potential hazard are fundamental to assumption of risk.

\section{Other Risk Management Strategies and Recommendations}

Only addressing the problems associated with drowning, diving, heat/cold/exhaustion, and obstacles is not sufficient for risk management at obstacle events. With the extreme nature of obstacle events it is essential for race organizers to implement other risk management strategies as well to protect the participants and their organization from financial loss. The following suggestions provide additional risk management strategies race organizers should implement as well.

\section{Insurance}

It is common for event organizers to look at insurance coverage and risk management as one and the same (Cotten, 2013c). Yet, while insurance coverage should absolutely be implemented by race organizers, it should not be the only risk management technique in place. Insurance coverage is a necessary piece to any risk management plan. Race organizers should make certain their insurance coverage is adequate to cover all staff, participants, volunteers, administrators, sponsors, and spectators that may be a part of the obstacle event.

Before obstacle racing becoming popular, event organizers struggled to find insurance companies willing to cover their events (Martin, 2013). However, with the expansion of the industry there are now a number of companies who specialize in obstacle racing insurance. For example companies such as, Westpoint Insurance, K2 Mud Run Insurance, and K \& K insurance, all offer insurance coverage specific to obstacle runs, mud runs, or extreme adventure races. Regardless of companies specializing in obstacle racing insurance, it is suggested that race organizers still carefully review their insurance policy to ensure an understanding of the policy. Property insurance and general liability insurance are both vital. Furthermore, it 
is recommended that race organizers should understand umbrella liability, liability protection for employees, and specific event insurance. How much protection is needed can be discussed and determined with an insurance agent that provides insurance for events such as obstacle runs.

\section{Waiver Administration and Management}

In 2010, Aubrey Anthony registered for the Filthy 5k in Virginia (Martin, 2013). The registration process included a mandatory online waiver, which she completed. But, after deciding not to participate, she gave her bib to a friend, Robert Fecteau, who ran in her place. Near the end of the course Fecteau dove into a mud pit and was paralyzed from the chest down. There was confusion as to whether Fecteau might have used Anthony's name when he initially received his race bib or whether he indicated he was given someone else's bib, nevertheless he was still allowed to participate without having completed a waiver. In learning from the specific facts in that incident, race organizers need to make sure that only those who have completed a waiver (i.e., online or hard copy) are allowed to participate. In addition, participant IDs should be required before issuing a bib to avoid potential abuse of online registration process.

Because of the elevated risk associated with many obstacle runs, the use of thorough, well-written waivers is essential. Waivers should be written for a specific event and be reviewed by a qualified attorney in the state they will be used to assure compliance with local laws and best practices. Moreover, a system must be initiated to ensure that every runner reads and signs a waiver before being allowed to participate. Finally, upon checking in for the event, it is prudent practice to require everyone to show a valid identification to ensure that the person who signed the waiver is the same one who is participating.

\section{Properly Trained Staff and Staffing}

Imperative to the success of any obstacle race event is employing sufficient numbers of personnel to handle the estimated volume of participants. It is recommended that all staff, both paid and volunteer, be well trained for their particular position, including training for how to respond to all foreseeable emergency situations. A staff member should be placed at each obstacle to make sure it is operating the way it was designed and that people are using it in the way it was intended. For instance, if a staff member is assigned to supervise a mud pit, he/she should be trained to make sure runners don't dive head first into the pit and to ensure that spectators are not encouraging runners to do so. Or, it may be to ensure that only a limited number of people attempt the obstacle at any one time. As for emergency response, the staff member should be trained how to properly respond to minor, major and catastrophic injuries that may occur at that obstacle. This may include first aid/CPR as well as training with emergency communications, whether it's with radios, cell phones or some other appropriate method. Knowing how to properly respond in an emergency is essential.

Staff should also be watching for potential problems with the obstacle such as loose bolts, frayed ropes or other unplanned changes to the obstacle. Likewise, if an unusual number of participants are being injured on a certain obstacle, the supervisor should be able to contact event managers to determine why the injuries 
are occurring. With that information, an adjustment may be made such as repairing a piece of equipment, warning upcoming runners how to stay safe or maybe even closing the obstacle before more injuries occur.

\section{Emergency Action Plan}

Participants of any high-risk sporting or recreational event today expect organizers to have a well thought out Emergency Action Plan (EAP). Medical emergencies occur frequently during obstacle races so event managers must be prepared for them. By identifying the emergencies most likely to occur, an EAP can be developed that will provide an optimal response to each. A good EAP will include having an adequate number of well-trained first responders on site with some located near the obstacles presenting the highest risk. Developing a good communication plan for staff throughout the course is essential. Being able to summon help and anticipating their timely arrival at the site of the incident is part of a good EAP. A well-planned emergency communication system is essential. All staff throughout the course must be able to communicate with event managers and first responders quickly if a need arises. Using radios is a common method of establishing communication on the course. Event staff needs to be trained who to contact and how to contact help if an emergency situation arises. Planning in advance how emergency responders can access, even remote parts of the course, is critical. Finally, planning for quick evacuation from the course is essential. Some events have become so big that roads coming into the site become jammed with no quick way in or out for emergency vehicles. An adequate space for landing a life-flight helicopter should be planned for and kept clear during the event. This landing area must be quickly accessible from all parts of the course.

\section{Conclusion}

With the popularity of obstacle course mud runs showing no signs of subsiding, event organizers must be cognizant of how to balance the allure of their events with the risks they present. From a legal perspective, organizers have a duty to provide a reasonably safe event, even though participants may assume the risks inherent in each obstacle. Negligence is by far the most frequent claim made by injured participants or surviving family members. This article provided a legal analysis of negligence and its defenses relevant to obstacle course events. Further, obvious and hidden hazards of obstacle courses were discussed along with strategies for effectively managing the risks of these events. Until a governing body establishes standards for event organizers to meet, it is imperative that each take on the task of mitigating unreasonable risks to provide the safe, yet challenging experience participant's desire.

\section{References}

Bassett, C. (2012, April 15). Athlete dies while running obstacle course in Fort Worth. McClatchy - Tribune Business News. Retrieved from http://ezproxy.lib.indiana.edu/ login?url=http://search.proquest.com/docview/1000364018?accountid=11620 
Beil, L. A race to the death. (October. 11, 2012). Men's Health. Retrieved from http://news. menshealth.com/health/mud-run-risk-factors

Branco v. Kearny Moto Park, 37 Cal. App. 4th 184; 43 Cal. Rptr. 2d 392; 1995 Cal. App. LEXIS 746; 95 Cal. Daily Op. Service 6243; 95 Daily Journal DAR 10195 (1995)

Brown v. City of New York, 69 AD 3d 893 - NY: Appellate Div., 2nd Dept. (2010)

Brown v. City of Peekskill, 212 AD2d 658 (1995)

Ciocchi v. Mercy Coll., 289 AD2d 362 (2001)

Clements, A., \& Otto, K.A. (2007). Headfirst aquatic incident court decisions: The plaintiff's odds. Journal of Legal Aspects of Sport, 17(1), 107-121.

Colucci v Nansen Park, 226 AD2d 336 (1996)

Cotten, D.J. (2013a). Defenses. In D. J. Cotten \& J. T. Wolohan (Eds. $6^{\text {th }}$ ed.), Law for recreation and sport managers (pp. 78-90). Dubuque, IA: Kendall Hunt.

Cotten, D.J. (2013b). Negligence theory. In D. J. Cotten \& J. T. Wolohan, (Eds., $6^{\text {th }}$ ed.), Law for recreation and sport managers, (pp. 42-53). Dubuque, IA: Kendall-Hunt.

Cotten, D.J. (2013c). Managing risk through insurance. In D. J. Cotten \& J. T. Wolohan (Eds. $6^{\text {th }}$ ed.), Law for recreation and sport managers (pp. 340-350). Dubuque, IA: Kendall Hunt.

Cotten, D.J., \& Cotten, M.B. (2005). Waivers and releases of liability (5th ed.). Statesboro, GA: Lulu.

Cotten, D.J., \& Young, S.J. (2007). Effectiveness of parental waivers, parental indemnification agreements, and parental arbitration agreements as risk management tools. Journal of Legal Aspects of Sports, 17(1), 52-80.

Dahl, M. (2013, Nov 24). 13 shocks in one race? ER doctors warn about 10,000 volt wires in mud runs. Retrieved from http://www.today.com/health/13-shocks-one-race-erdoctors-warn-about-10-000-2D11641896

Death races. (2013). Ever man dies, but not every man lives. Retrieved from http://www. peak.com/death-races

Fried, G. (1999). Safe at first. Durham, NC: Carolina Academic Press.

Gabrielsen, M.A., \& Spivey-Teslow, M. (1990). Diving injuries the etiology of 486 case studies with recommendations for needed action. Fort Lauderdale, FL: Nova University Press.

Gregory, S. (2013). Triathlons are for wimps. Time, 181(3), 46-49.

Grimley, B. (2013, Jan 8). Silverdale mud run organizers sued over course design. Kitsap Sun. Retrieved from http://www.kitsapsun.com/news/2013/jan/08/silverdale-mud-runorganizers-sued-over-course/?comments_id=563849\#axzz2ov1AKeYO

Heil, N. (2011, December 8). American gladiators. Outside Online. Retrieved from http:// www.outsideonline.com/templates/Outside_Print_Template?content $=134768403$

Hillen, T. (2013, July 3). Tough Mudder runners sick after race event at Michigan International Speedway. Wood TV Channel 8. Retrieved from http://www.woodtv.com/news/ local/se-mich/tough-mudders-sick-after-competition

Hyland v. State of New York, 100 N.Y.2d 504; 793 N.E.2d 411; 762 N.Y.S.2d 874; 2003 N.Y. LEXIS 1383 (2003).

Joseph v. New York Racing Assn., 28 AD3d 105, 108 (2006).

Kahn v. East Side Union High School Dist., 117 Cal.Rptr.2d 356 (2002), Court of Appeals of California, Sixth District., February 27, 2002.

Kazlow v. City of New York, 253 AD2d 411 (1998)

Keneally, S. (2012, October 22). Playing dirty. Outside Online. Retrieved from http://www. outsideonline.com/outdoor-adventure/multisport/Playing-Dirty-November-2012. html?page $=$ all

Knight v. Jewett, 3 Cal. 4th 296, 11 Cal. Rptr. 2d 2, 34 P.2d 696 (1992)

Krogh, R. (2013, April 23). Tough Mudder's first death in context. Outside Online. Retrieved from http://www.outsideonline.com/outdoor-adventure/multisport/A-History-ofAccidents-in-Tough-Mudder.html?page=all 
Luna v. Vela, 169 Cal. App. 4th 102; 86 Cal. Rptr. 3d 588; 2008 Cal. App. LEXIS 2413 (2008) Maddox v. City of New York, 66 NY2d 270 (1985)

Manoly v. City of New York, 29 AD3d 649 (2006)

Martin, H. (2013, September 14). In big-money obstacle runs, mud and risks are par for the course. Los Angeles Times. Retrieved from http://articles.latimes.com/2013/sep/14/ business/la-fi-mud-runs-20130914

Martin v. State of New York, 833 N.Y.S.2d 706, 29 A.D.3d 905 (2007).

Meltzer, K. (2012, March 23). Adventure racing sweeping the nation. ThePostGame. Yahoo! Sports. Retrieved from http://www.thepostgame.com/blog/training-day/201203/ adventure-races-sweeping-nation

Merson v. Syosset Cent. School Dist., 286 AD2d 668 (2001).

Miller v. Kings Park Cent. School Dist., 54 AD3d 314 (2008).

Morales v. Coram Materials Corp., 64 AD3d 756, 758 (2009).

Mullins, N. (2012). Obstacle course challenges: History, popularity, performance demands, effective training, and course design. Journal of Exercise Physiology online, 15(2), 100-128.

Musante v. Oceanside Union Free School Dist., 63 AD3d 806 (2009).

Newsome, P. (2013, August 19). Man left paralyzed from Richmond mud run, trying to sue sports backers. NBC 12, Retrieved from http://www.nbc12.com/story/23091334/manleft-paralyzed-from-richmond-mud-run-trying-to-sue-sports-backers

Obstacle course races increase in popularity, athletes thirst for higher level of competition. (2013) National Academy of Sports Medicine, Retrieved from http://www.nasm.org/ docs/default-source/press-releases/pressrelease_cesrace_052013.pdf?sfvrsn=6

Obstacle racing 2013: The complete guide. (2013, August 1). Outside Online. Retrieved from http://www.outsideonline.com/outdoor-adventure/multisport/Love-that-MuddyWater-Guide-to-Obstacle-Racing.html

Pan, P. (2013, April 09). Gwinnett county man paralyzed after fall during obstacle course run. Fox 5, Retrieved from http://wftc.membercenter.worldnow.com/story/21923794/ gwinnett-county-man

Parsons v. Crown Disposal Co., 15 Cal. $4^{\text {th }} 456$, (1997).

Perez, A.J. (2013, October 7). A growing race with big risks. The New York Times. Retrieved from http://www.nytimes.com/2013/10/08/sports/racing-at-the-risk-of-your-life.html

Ribaudo v. La Salle Inst., 45 AD3d 556 (2007).

Ridley, G. (2012, December 29). Hope student files lawsuit after he was paralyzed during Genessee County warrior dash in 2011. MLive, Retrieved from http://www.mlive.com/ news/flint/index.ssf/2012/12/hope_college_student_files_law.html

Roberts v. Boys \& Girls Republic, Inc., 51 AD3d 246, 850 NYS2d 38, 2008 N.Y. App. Div. LEXIS 75 (N.Y. App. Div. 1st Dep't, 2008)

Rosencrans v. Dover Images, 192 Cal. App. 4th 1072; 122 Cal. Rptr. 3d 22; 2011 Cal. App. LEXIS 177 (2011).

Rubinkam, M. (2012, August 13). Muddy much? Millions drawn to obstacle courses. Associated Press. Retrieved from http://finance.yahoo.com/news/muddy-much-millionsdrawn-obstacle-courses-063315241-spt.html

Sa v. Red Frog Events, LLC., No.2:13-cv10294, 2013 U.S. Dist, LEXIS 151355(S.D.M.I. Dec 29, 2013).

Seidler, T.L. (2012). Safe facilities: Conducting a facility risk review. In H. Appenzeller (Ed.), Risk Management in sport: Issues and Strategies (3rd ed., pp. 457-468). Durham, NC: Carolina Academic Press.

Sheppard v. Midway R-1 School District, 904 S.W.2d 257 (Mo.App. W.D., 1995)

Shin v. Ahn, 42 Cal. 4th 482, 64 Cal. Rptr. 3d 803, 165 P.3d 581, 2007 Cal. LEXIS 9377 (2007)

Swan, P., Otago, L., Finch, C.F., \& Payne, W.R. (2009). The policies and practices of sports governing bodies in relation to assessing the safety of sports grounds. Journal of Science and Medicine in Sport, 12, 171-176. doi:10.1016/j.jsams.2007.12.004 
Sykes v. County of Erie, 94 NY2d 912 (2000)

Trevett v. City of Little Falls, 6 NY3d 884 (2006)

Tunison, J. (2011, August 2). Hope College student paralyzed in Warrior Dash landed wrong way while diving into mud pit, organizer says. MLive. Retrieved from http://www. mlive.com/news/grand-rapids/index.ssf/2011/08/hope_college_student_paralyzed.html

Turcotte v. Fell, 68 N.Y.2d 432, 502 N.E.2d 964, 510 N.Y.S.2d 49 (1986)

Wells, C. (2013, 24). Injuries after Tough Mudder included heart attacks, electrical shocks. McClatchy - Tribune Business News. Retrieved from http://ezproxy.lib.indiana.edu/ login?url=http://search.proquest.com/docview/1337850590?accountid=11620

Wells, C., \& Wood, P. (2013a, May 25). In rise of obstacle course races, fun comes with risk. McClatchy - Tribune Business News. Retrieved from http://ezproxy.lib.indiana. edu/login?url=http://search.proquest.com/docview/1355276230?accountid=11620

Wells, C., \& Wood, P. (2013b, May 26). Gutsy race heavy risk. Baltimore Sun. Retrieved from http://www.lexisnexis.com.ezproxy.lib.indiana.edu/hottopics/lnacademic/

Williams, P. (2012). Down \& dirty. Sports Business Journal, (September 24-30), 1. Retrieved from http://www.sportsbusinessdaily.com/Journal/Issues/2012/09/24/In-Depth/ Obstacle-races.aspx

Woodard, T. (2012, April 15). Man's body discovered after 'mud run' in Fort Worth. WFAA. Retrieved from http://www.wfaa.com/news/local/Mans-body-discovered-after-OriginalMud-Race-in-Fort-Worth-147497265.html

Woods, E. (2013). A death at Tough Mudder. Outside Magazine. Retrieved from http:// www.outsideonline.com/outdoor-adventure/multisport/Man-Under-Avishek-SenguptaTough-Mudder-Death.html\#

Young, J.S., Burns, P.E., Bowen, A.M., \& McCutchen, R. (1982). Spinal cord injury statistics. Phoenix, AZ: Good Samaritan Medical Center.

Ziegelmeyer v. United States Olympic Comm., 7 NY3d 893 (2006) 